\title{
Prinsip Pengadaan Tanah Bagi Kepentingan Umum
}

\author{
Agung Basuki Prasetyo \\ Fakultas Hukum, Universitas Diponegoro \\ agung_basuki@live.undip.ac.id
}

\begin{abstract}
This study aims to find out how the principle of land acquisition for the public interest. The principle is only sought based on the legal norms that apply in Indonesia. This research is a normative legal research based on a legal regulation approach. the results of the study show that the principle of land acquisition for the public interest must meet the provisions of Law No. 2 of 2012 concerning Land Procurement for Development in the Public Interest.
\end{abstract}

Keywords: Land Procurement, Public Interest, Land

\begin{abstract}
Abstrak
Penelitian ini bertujuan untuk mengetahui bagaimanakah prinsip pengadaan tanah bagi kepentingan umum. Prinsip tersebut hanya dicari berdasarkan pada norma hukum yang berlaku di Indonesia. Penelitian ini merupakan penelitian hukum normatif yang berdasarkan pendekatan peraturan perundang-undangan. Hasil penelitian menunjukan bahwa prinsip pengadaan tanah bagi kepentingan umum harus memenuhi sebagaimana ketentuan Undang-Undang No. 2 Tahun 2012 Tentang Pengadaan Tanah Bagi Pembangunan Untuk Kepentingan Umum.
\end{abstract}

Kata Kunci: Pengadaan Tanah, Kepentingan Umum, Pertanahan

\section{A. Pendahuluan}

Pengelolaan aset desa yang berupa tanah desa atau tanah bengkok tidak boleh dilakukan dengan semena-mena atas kewenangan pribadi dari seorang Kepala Desa semata namun telah diatur dalam peraturan perundang-undangan yang sah. Pengelolaan kekayaan milik desa dilaksanakan berdasarkan asas kepentingan umum, fungsional, kepastian hukum, keterbukaan, efensiensi, ekfektivitas, akuntabilitas, dan kepastian nilai ekonomi. Pengelolaan milik desa dibahas oleh kepala desa bersama Badan Permusyawaratan Desa berdasarkan tata cara pengelolaan kekayaan milik Desa yang diatur dalam Pasal 77ayat (3) Undang-Undang No. 6 Tahun 2014 Tentang Desa. 
Peraturan Pemerintah No. 47 Tahun 2015 sebagai perubahan atas Peraturan Pemerintah No. 43 Tahun 2014 tentang Peraturan Pelaksanaan Undang-Undang No.6 Tahun 2014 tentang desa, dalam PP tersebut dilakukan perubahan pada Pasal 100 tentang belanja desa yaitu dengan adanya tambahan aturan baru tentang status tanah bengkok. Aturan baru tersebut menyebutkan bahwa pendapatan yang bersumber dari hasil pengelolaan tanah bengkok tidak termasuk dalam belanja desa, yang ditetapkan dalam anggaran pendapatan belanja desa dan hasil pengelolahan tanah bengkok tersebut dapat digunakan untuk tambahan tunjangan kepala desa dan perangkat desa selain penghasilan tetap dari tunjangan dari APB Desa.

Aturan mengenai tanah bengkok yang diatur dalam Peraturan Gubernur Daerah Istimewa Yogyakarta selanjutnya disingkat Pergub. Hal tersebut diatur dalam Pergub Daerah Istimewa Yogyakarta No. 34 Tahun 2017 tentang Pemanfaatan Tanah Desa. Pada Pasal 36 disebutkan bahwa tanah pelungguh (tanah bengkok) diberikan kepada Kepala Desa dan Perangkat Desa selama menduduki jabatan sebagai penghasilan tambahan. Pendapatan pelungguh dibagi untuk pemerintah desa dan penerima pelungguh besarannya diatur dalam Peraturan Desa.

Eksistensi tanah bengkok mulai memudar dengan sendirinya akibat pengaruh dari luar maupun dari dalam desa itu sendiri. Seperti halnya tanah bengkok yang berada di Desa Palihan, Kecamatan Temon, Kabupaten Kulon Progo akan tergusur dengan adanya rencana pembangunan bandara baru yang direncanakan dibangun di daerah tersebut. Itulah yang melatar belakangi penulis dalam upaya menyelesaikan penulisan hukum untuk meneliti bagaimana penyelesaian sengketa yang terjadi di Desa Palihan, Kecamatan Temon, Kabupaten Kulon Progo.

Permasalahan tersebut berawal dari upaya pembangunan bandara New Yogyakarta International Airport, yang diharapkan bisa memajukan perekonomian, pariwisata dan peningkatan kesejahteraan di Daerah Istimewa Yogyakarta itu sendiri. Tetapi pada dasarnya masyarakat tidak menghendaki pembangunan bandara tersebut karena mayoritas warga Desa Palihan bermata pencaharian sebagai petani dan yang menjadi rencana pembanguanan berada pada lahan pertanian mereka. Dengan komoditas tanaman pokok seperti padi, jagung, sayuran, cabai, terong, gambas, dan buah-buahan.

Pergub Daerah Istimewa Yogyakarta No. 34 Tahun 2017 tentang pemanfaatan tanah desa memperbolehkan adanya pelepasan tanah untuk pembangunan New Yogyakarta International Airport tetapi harus mendapatkan tanah pengganti, yang pada Pasal 44 menyatakan bahwa tanah desa dapat dilepaskan untuk pembanguan bagi 
kepentingan umum. Dalam Pergub Daerah Istimewa Yogyakarta No. 34 Tahun 2017 tentang pemanfaatan tanah desa pada Pasal 48 bahwa dalam hal tanah desa yang dilepaskan untuk pembangunan kepentingan umum, harus ditukar dalam bentuk tanah pengganti dan menjadi tanggung jawab instansi yang mengajukan pelepasan. Tanah pengganti harus senilai dengan Tanah Desa yang dilepaskan.

\section{B. Pembahasan}

\section{Pengadaan Tanah Bagi Kepentingan Umum}

Pengertian pengadaan tanah menurut John Salindeho memiliki arti menyediakan kita untuk mencapai keadaan ada, karena didalam mengupayakan dan menyediakan sudah terselip arti mengadakan dalam keadaan tersebut. Sedangkan dalam mengadakan tentunya kita menemukan suatu yang tersedia, kecuali tidak berbuat demikian, jadi kedua istilah tersebut sama namun tampak berbeda, mempunyai arti yang menuju kepada suatu perbuatan untuk mengadakan agar tersedia tanah bagi kepentingan pemerintah. ${ }^{1}$

Sedangkan menurut Imam Koeswahyono pengadaan tanah sebagai suatau perbuatan hukum yang dilakukan oleh pemerintah untuk mendapatkan tanah bagi kepentingan tertentu dengan cara memberikan ganti kerugian kepada si empunya (baik perorangan atau badan hukum) tanah menurut tata cara dan besaran nominal tertentu. $^{2}$

Terdapat berbagai macam pengertian pengadaan tanah yang diatur dalam pengaturan perundang-undangan. Perubahan peraturan akan diikuti pola dengan perubahan pengertian dari lembaga pengadaan tanah itu sendiri.

Istilah pengadaan tanah dipergunakan pertama kali di dalam Keputusan Presiden Nomor 55 Tahun 1993 tentang Pengadaan Tanah Bagi Pembangunan Untuk Kepentingan Umum di dalam ketentuan Pasal 1 angka 1 pengadaan tanah didefinisasikan sebagai berikut :

Pengadaan tanah adalah setiap kegiatan untuk mendapatkan tanah dengan cara memberikan ganti rugi kepada yang berhak atas tanah tersebut.

Pada tahun 2012 pemerintah memberlakukan Undang-Undang Nomor 2 Tahun 2012 tentang Pengadaan Tanah Bagi Pembangunan Untuk Kepentingan Umum dan

\footnotetext{
${ }^{1}$ John Salindeho, op.cit, hlm. 31.

2 Imam Koeswahyono, Artikel, Melacak Dasar Konstitusional Pengadaan Tanah Untuk Kepentingan Pembangunan Bagi Umum, 2008, hlm. 1.
} 
Peraturan Presiden Republik Indonesia Nomor 71 Tahun 2012 Tentang Penyelenggaraan Pengadaan Tanah Bagi Pembangunan Untuk Kepentingan Umum. Ketentuan Pasal 1 angka 2 mendefinisikan pengadaan tanah sebagai berikut :

Pengadaan tanah adalah kegiatan menyediakan tanah dengan cara memberi ganti kerugian yang layak dan adil kepada pihak yang berhak.

Beberapa pendapat para sarjana mengenai pengadaan tanah dikutip sebagai perbandingan antara lain :

a. Boedi Harsono

Perbuatan hukum yang berupa melepaskan hubungan hukum yang semula ada antara pemegang hak dan tanahnya yang diperlukan, dengan pemberian imbalan dalam bentuk uang, fasilitas atau lainnya, melalui musyawarah untuk mencapai kata sepakat antara empunya tanah dan pihak yang memerlukan. ${ }^{3}$

b. Gunanegara

Proses pelepasan hak atas kepemilikan orang atas tanah dan/atau benda-benda yang ada di atasnya yang dilakukan secara sukarela untuk kepentingan umum. ${ }^{4}$

Berdasarkan definisi-definisi di atas, pengadaan tanah terdiri dari unsur-unsur sebagai berikut :

a) Perbuatan hukum berupa pelepasan hak atas tanah menjadi tanah Negara

b) Pelepasan hak atas tanah untuk kepentingan umum

c) Perbuatan hukum didasarkan pada musyawarah dan kesukarelaan

d) Disertai ganti rugi yang adil dan layak.

Pasal 1 butir 6 Undang-Undang No.2 Tahun 2012 menyatakan kepentingan umum adalah kepentingan bangsa, Negara, dan masyarakat yang harus diwujudkan oleh pemerintah dan digunakan sebesar-besarnya untuk kemakmuran rakyat.

Pada Bab II undang-undang ini menjelaskan asas dan tujuan dari pengadaan tanah untuk kepentingan umum, Pasal 2 berbunyi Pengadaan Tanah untuk kepentingan umum dilaksanakan berdasarkan asas :

a) Kemanusian;

Pengadaan tanah harus memberikan perlindungan serta penghormatan terhadap hak asasi manusia, harkat, dan martabat setiap warga Negara dan penduduk Indonesia secara proporsional.

\footnotetext{
${ }^{3}$ Boedi Harsono, op.cit., hlm. 7.

${ }^{4}$ Gunanegara, Rakyat dan Negara Dalam Pengadaan Tanah Untuk Pembangunan, (Jakarta : Tata Nusa, 2008), hlm. 11 .
} 
b) Keadilan;

Memberikan jaminan penggantian yang layak kepada pihak yang berhak dalam proses pengadaan tanah sehingga mendapatkan kesempatan untuk dapat melangsungkan kehidupan yang baik.

c) Kemanfaatan

Hasil pengadaan tanah mampu memberikan manfaat secara luas bagi kepentingan masyarakat, bangsa dan negara.

d) Kepastian;

Memberikan kepastian hukum tersedianya tanah dalam proses pengadaan tanah untuk pembangunan dan memberikan jaminan kepada pihak yang berhak untuk mendapatkan ganti kerugian yang layak.

e) Keterbukaan;

Pengadaan tanah untuk pembangunan dilaksanakan dengan memberikan akses kepada masyarakat untuk mendapatkan informasi yang berkaitan dengan pengadaan tanah.

f) Kesepakatan;

Proses pengadaan tanah dilakukan dengan musyawarah para pihak tanpa unsur paksaan untuk mendapatkan kesepakatan bersama.

g) Keikutsertaan;

Dukungan dalam penyelenggaraan pengadaan tanah melalui partisipasi masyarakat, baik secara langsung maupun tidak langsung, sejak perencanaan sampai dengan kegiatan pembangunan.

h) Kesejahteraan;

Pengadaan tanah untuk pembangunan dapat memberikan nilai tambah bagi kelangsungan kehidupan Pihak yang berhak dan masyarakat secara luas.

i) Keberlanjutan;

Kegiatan pembangunan dapat berlangsung secara terus menerus, berkesinambungan, untuk mencapai tujuan yang diharapkan.

j) Keselarasan;

Pengadaan tanah untuk pembangunan dapat seimbang dan sejalan dengan kepentingan masyarakat dan negara.

Pada Pasal 3 menyatakan Pengadaan Tanah untuk kepentingan umum bertujuan menyediakan tanah bagi pelaksanaan pembangunan guna meningkatkan kesejahteraan 
dan kemakmuran bangsa, negara, dan masyarakat dengan tetap menjamin kepentingan umum yang berhak.

\section{Ganti Kerugian Dalam Pengadaan Tanah Untuk Kepentingan Umum menurut}

\section{Undang-Undang No. 2 Tahun 2012 Tentang Pengadaan Tanah Bagi}

\section{Pembangunan Untuk Kepentingan Umum}

Pasal 1 butir 10 undang-undang No. 2 Tahun 2012 menyatakan ganti kerugian adalah penggantian yang layak dan adil kepada pihak yang berhak dalam proses pengadaan tanah. Pasal 36 undang-undang ini menyatakan ganti kerugian dalam pengadaan tanah untuk kepentingan umum dapat berupa :
a. uang;
b. tanah pengganti;
c. permukiman kembali;
d. kepemilikan saham; atau
e. bentuk lain yang disetujui oleh kedua belah pihak.

Pasal 37 ayat (1) dalam undang-undang ini menetapkan dasar perhitungan ganti rugi ditentukan bahwa Lembaga Pertanahan melakukan musyawarah dengan pihak yang berhak dalam waktu paling lama 30 (tiga puluh) hari kerja sejak hasil penilaian dari penilai disampaikan kepada Lembaga Pertanahan untuk menetapkan bentuk dan/atau besarnya ganti kerugian berdasarkan hasil penilaian ganti rugi. Pasal 37 ayat (2) menyatakan bahwa hasil kesepakatan dalam musyawarah menjadi dasar pemberian ganti Kerugian kepada pihak yang berhak yang dimuat dalam berita acara kesepakatan.

Pasal 41 ayat (1) dalam undang-undang ini mengatur pemberian ganti kerugian diberikan langsung kepada pihak yang berhak berdasarkan hasil penilaian yang ditetapkan dalam musyawarah. Pasal 41 ayat (2) menyatakan pada saat penerimaan ganti kerugian, pihak yang berhak menerima ganti kerugian wajib melakukan pelepasan hak dan menyerahkan bukti penguasaan atau kepemilikan objek pengadaan tanah kepada Instansi yang memerlukan tanah melalui Lembaga Pertanahan.

\section{Pengaturan Pelepasan dan Pengganti Tanah Desa Menurut Pergub Daerah}

\section{Istimewa Yogtyakarta No. 34 Tahun 2017 Tentang Pemanfaatan Tanah Desa}

Peraturan Gubernur ini mengatur secara jelas tentang pelepasan dan penggantian dari tanah desa. Pasal 44 Pergub ini menjelaskan bahwa tanah desa dapat dilepaskan untuk pembangunan bagi kepentingan umum, pengganti tanah masyarakat yang terkena 
pengadaan tanah bagi pembangunan untuk kepentingan umum, kepentingan relokasi hunian karena terjadi bencana, dan tukar-menukar atau penjualan tanah desa sebagai upaya penyelesaian permasalahan tanah desa.

Pelepasan tanah desa sendiri harus memenuhi syarat sebagaimana disebutkan dalam Pasal 46 ayat (1) sebagai berikut :

a. izin dari Kasultanan atau Kadipaten, dan

b. menyediakan tanah pengganti yang senilai dengan tanah desa yang dilepaskan.

Tanah Desa yang dilepaskan harus ditukar dengan tanah pengganti (Pasal 48 ayat 1). Penyediaan tanah pengganti terhadap tanah desa yang dilepaskan menjadi tanggung jawab instansi yang mengajukan pelepasan tanah (Pasal 48 ayat 2). Tanah pengganti harus sesuai dengan tanah desa yang dilepaskan (Pasal 48 ayat 3). Apabila penggantian tanah tidak dapat dilaksanakan pada tahun anggaran berjalan, maka penggantian tanah desa dapat berupa uang untuk membeli tanah pengganti yang senilai (Pasal 48 ayat 4).

Tanah pengganti sendiri diutamakan berlokasi di desa yang bersangkutan (Pasal 49 ayat 1), tapi apabila tidak tersedia di desa tersebut maka tanah pengganti dapat diganti dengan tanah di desa lain dalam satu kecamatan (Pasal 49 ayat 2). Dan apabila tanah pengganti tidak tersedia dalam satu kecamatan maka tanah pengganti dapat berada di luar kecamatan dalam satu Kabupaten (Pasal 49 ayat 3).

Instansi yang mengajukan pelepasan tanah desa dapat meminta bantuan kepada Bupati untuk penyediaan tanah pengganti (Pasal 50 ayat 1), Bupati menindaklanjuti dengan membentuk panitia (Pasal 50 ayat 2). Panitia ini sebagai pihak yang mewakili pemerintah desa dalam melaksanakan pelepasan dan pengadaan tanah pengganti tanah desa (Pasal 50 ayat 3). Panitia pelepasan tanah desa dan pengadaan tanah pengganti menurut Pasal 51 ayat (1) Pergub ini terdiri dari :

a. Bupati;

b. unsur satuan kerja perangkat daerah kabupaten;

c. unsur kecamatan;

d. unsur kantor pertanahan; dan

e. Kepala desa.

Panitia pelepasan tanah dan pengadaan tanah pengganti tanah desa memiliki tugas yang tercantum dalam Pasal 51 ayat (2), yaitu:

a. melakukan persiapan pelepasan dan pengadaan tanah pengganti Tanah Desa

b. melakukan musyawarah objek pengadaan tanah pengganti tanah desa 
c. menetapkan nilai ganti kerugian atas Tanah Desa yang dilepasakan berdasarkan hasil penilaian ganti kerugian dari penilai publik

d. menetapkan nilai tanah pengganti Tanah Desa

e. menyaksikan pembayaran tanah desa yang dilepaskan

f. menandatangani berita acara kesepakatan harga tanah desa yang dilepaskan

g. menandatangani berita acara pelepasan Tanah Desa

h. menandatangani berita acara kesepakatan harga tanah pengganti tanah desa; dan

i. menandatangani berita acara pelepasan tanah pengganti tanah desa.

\section{Simpulan}

Prinsip pengadaan tanah bagi kepentingan umum harus memenuhi sebagaimana ketentuan Undang-Undang No. 2 Tahun 2012 Tentang Pengadaan Tanah Bagi Pembangunan Untuk Kepentingan Umum. Pasal 1 butir 10 undang-undang No. 2 Tahun 2012 menyatakan ganti kerugian adalah penggantian yang layak dan adil kepada pihak yang berhak dalam proses pengadaan tanah. Pasal 36 undang-undang ini menyatakan ganti kerugian dalam pengadaan tanah untuk kepentingan umum dapat berupa : a. uang; b. tanah pengganti; c. permukiman kembali; d. kepemilikan saham; atau e. bentuk lain yang disetujui oleh kedua belah pihak.

\section{Daftar Pustaka}

Amiruddin, Zainal Asikin. 2004. Pengantar Metode Penelitian Hukum. Jakarta : Raja Grafindo Persada.

Bzn, Ter Har. 1983. Asas-Asas dan Susunan Hukum Adat. Jakarta : Pradya Pramita.

Gunanegara. 2008. Rakyat dan Negara Dalam Pengadaan Tanah Untuk Pembangunan Umum. Jakarta : Tata Nusa.

Harsono, Boedi. 1995. Hukum Agraria Indonesia, Sejarah Pembentukan UndangUndang Pokok Agraria, Isi dan Pelaksanaannya. Jakarta : Djembatan. 2002. Menuju Penyempurnaan Hukum Tanah Nasional. Jakarta : Universitas Trisakti.

KBBI, Tim. 2001. Kamus Besar Bahasa Indonesia. Jakarta : Balai Pustaka.

Kansil, C.S.T. 2001. Kamus Istilah Aneka Hukum. Jakarta : Sinar Harapan..

Parlindungan, A.P. 1993. Komentar Atas Undang-Undang Pokok Agraria. Bandung : Mandar Maju.

Perangin, Effendi. 1994. Hukum Agraria Di Indonesia, Suatu Telaah Dari Sudut Pandang Praktisi Hukum. Jakarta : Raja Grafindo Persada.

Salindeho, John. 1987. Masalah Tanah Dalam Pembangunan. Jakarta : Sinar Grafika.

Salle, H.A, dkk. 2010. Hukum Agraria. Makasar : AS Publishing. 
Santoso, Urip. 2006. Hukum Agraria \& Hak-Hak Atas Tanah. Jakarta : Prenada.

Suandra, I Wayan. 1991. Hukum Pertanahan Indonesia. Jakarta : Rieka Cipta.

Soekanto, Soerjono. 1986. Pengantar Penelitian Hukum. Jakarta : UI Press.

Supriadi. 2009. Hukum Agrar' ' tkarta : Sinar Grafika.

Syamsudin, M. 2007. Oprasion si Penelitian Hukum. Jakarta : Raja Grafindo Persada.

Widjaja, H.A.W. 2007. Penyelengaraan Otonomi di Indonesia. Jakarta : Rajawali Pers. Ahmad dan Rizaldi. 2017. Jalan Berliku Menuju Bandara Baru, angkasapura magazine. Koeswahyono, Imam. 2008. Melacak Dasar Konstitusional Pengadaan Tanah Untuk

Kepentingan Pembangunan Bagi Umum. Artikel 